\title{
THE SYSTEM OF WORLD GOLF RANKING AMONG AMATEUR PLAYERS - WAGR
}

\author{
Tereshchuk M.V.
}

National University of Physical Education and Sport of Ukraine

\begin{abstract}
Annotation. Purpose: justify the particular rating-WAGR and determine its value. Material: More than 40 references, including analysis of 8 protocols of Ukraine competition in golf. Results: The features and significance of the world rankings in golf among amateur players. Displaying ranking tournaments in accordance with the system of WAGR and justified the use of the conversion of the results to determine the specific places the player in the rankings. In Ukraine, held six WAGR-Tournament, the first tournament was held in 2011. Today in the world ranking of amateur players is one player from the Ukraine. Conclusions: It was found that the top-WAGR determines the level of development of the national golf federations and influence in the international arena. For the selection of athletes for the summer Youth Olympic Games is used world-rated golf amateur players (WAGR) among boys and girls.
\end{abstract}

Key words: golf, rating, WAGR, amateur, player.

\section{Introduction}

Nowadays amateur sports are spread much less than in the past. R\&A Rules Limited (R\&A) and Association of USA golf (USGA) control golf and golf rules in the whole world; they have been reviewing profoundly Golf rules, in particular for amateurs, during recent four years [7, 19].

At present, in Ukraine all-Ukrainian golf competitions are conducted for amateurs, but with every year we can see change in competition schedules, in which tournaments for professionals appear. Just owing to this fact we took for study analysis of world amateur ranking (WAGR), but not ranking for professionals.

For amateur golf player it is prestigious to be in WAGR [www.wagr.com].

In Ukraine the problem of amateur golf players is insufficient information. Since 2011 in Ukraine competitions, included in WAGR [www.ukrgolf.org] schedule have been conducting but players can not mark out for themselves competitions of priority for season. Some players-amateur choose commercial, fan competitions. In world practice a number of specialists deal with this direction $[4,11,17,18,20]$; statistical data are published. In Ukraine there have been no such researches; significance and place of WAGR tournaments have not been studied and these make our topic rather urgent.

The present work has been fulfilled in compliance with combined plan of SRW in sphere of physical culture and sports for 2011-2015 and as per approved topical plan of Ministry of education and science, youth and sports of Ukraine by topic 1.2. "Modern professional sports and the ways of their development in Ukraine".

Purpose, tasks of the work, material and methods

The purpose of the work is to analyze principles of WAGR and determine its meaning.

The methods of the research: systemic analysis, analysis of scientific-methodic and specialized literature, internet resources, comparison and abstracting.

Analysis of literature sources and internet resources permitted to generalize modern views in respect to world ranking for amateur golf players and determine its importance.

\section{Results of the research}

The fact that golf player is an amateur is a condition of his participation in golf competitions everywhere in the world. The person, who violates rules, can be deprived of amateur status and, as a result, loose right to participate in amateur competitions. According to golf rules, approved by R\&A Rules Limited and by US Golf Association for 20122015 amateur player is any person, who plays golf not professionally but to test himself; not for having financial profit, but only to pass leisure time [7, 19].

World Amateur Golf Ranking (WAGR) - is the only ranking for amateur players, which was founded by R\&A for evaluation of golf players' level and coordination of international tournaments [www.wagr.com].

In 2004 R\&A creates WAGR as criterion of selection for amateur championships. In 2007 the ranking was, for the first time, presented for everybody, i.e. amateur golf started to unite around single ranking quite recently. To day ranking for male players is formed on the base of results of 1800 test tournaments in 70 countries of Europe and includes more than 5000 players. Female ranking was created in 2011; it covers 1350 test tournaments and includes 3100 players [1, $5,7,17]$.

World ranking of amateur golf is realized on the base of thousands of amateur tournaments. Ranking system selects the best sportsmen in the world and it is based on mean quantity of scores, received by sportsmen, considering competitions of cycle for recent 52 weeks.

Nowadays WAGR is analogue, which is the most approximated to world golf professionals' ranking - Official World Golf Ranking [www.wagr.com].

Every week ranking is renewed: every Wednesday at 12:00 by Greenwich. Thus, the ranking is not only the most complete as on to day, but it promptly reflects changes in distribution of players' levels on sport golf arena. 
Introducing of a tournament in official schedule of European competitions is followed by its ranking in compliance with WAGR. Tournament's ranking depends on its status and importance, on level of golf's progress in country, on handicaps of players-participants and etc.

WAGR categories are divided into:

1) elite tournaments: The Amateur, Asian Amateur, European Amateur and US Amateur Championships (Men's WAGR) and Ladies 'British Amateur, NCAA Championship, US Women's Amateur и Women's European Amateur Championship (Women's WAGR).

2) tournaments of categories A-F, awarded by results of WAGR ranking:

- $\mathrm{A}=1-30$ places;

- B = 31-100 places;

- $\mathrm{C}=101-200$ places;

- D = 201-300 places;

- $\mathrm{E}=301-400$ places;

- $\mathrm{F}=401$ place and lower.

Further, tournament's category determines place of its winners or participants in WAGR ranking [www.usga.org].

For example, category $\langle\mathrm{F}\rangle$ is initial one and winners, who take $1^{\text {st }}$ and $2^{\text {nd }}$ places by results of this category's tournament, get in WAGR ranking. To compare with: in tournaments of category "E" (one level higher) not 2 but 4 first places go in ranking; For category "A" - 40 first places. Participants of elite tournaments, listed above, shall pass only qualification for getting in WAGR $[3,14]$.

Committees of golf tournaments use ranking as one of conditions of players' selection and their admission to registration. It concerns both national championships, federation tournaments (members of EGA) and international tournaments of higher level, like British Amateur Championship and European Golf Amateur Championship. For example, for participation in European amateur championship (Sweden, August 3rd - 6th, 2011) golf player should have taken 1-1200 position in WAGR [www.kievgolfclub.com].

So, it was determined that quantity of players of country who got in ranking (WAGR - ranking players) determines level of national golf progress and weight of federation on international arena. Quantity of WAGR - players also is one of conditions, owing to which country receives right to accept great international golf competitions, including elite championships of amateur golf.

In order to get in ranking player shall take place of credit at one of WAGR-tournaments. Having taken place in ranking, golf player can further improve it, taking part in WAGR tournaments.

For determination of certain player's place in ranking they use system of results' converting Stroke Play (or Match Play) in scores Stroke Play Ranking Points (or Match Play Ranking Points). Besides, they consider accumulated bonus scores and total quantity of played test rounds Match Play and Stroke Play. Calculation formula is presented on site WAGR $[1,11,12,13]$.

In February 2011 WAGR ranking was officially recognized as the greatest national golf federation United States Golf Association (USGA) [www.usga.org]. It became an approval of its competitiveness and objectivity in comparison with other international rankings of amateur golf players.

Cooperation of R\&A and USGA in unification of ranking of amateur golf players in all the world witnesses that golf world in conditions of globalizing encourages international contacts and strives to find reasonable balance between two poles of golf culture - of Europe and USA.

For example, already in 201150 best players in male WAGR ranking could take part in US Open tournament without qualification. Earlier format of qualification rounds (in 1 day) complicated significantly access of European players to this tournament.

In 2014 for the first time golf was included in program of $2^{\text {nd }}$ summer Junior Olympic Games (Nanjing, China). For selection and qualification of sportsmen they use world ranking for amateur golf players (WAGR) cfor boys and girls for last 52 weeks up to July $8^{\text {th }}, 2014$. 26 of National Olympic committees and federations will receive qualification places for participation in individual and team competitions at $2^{\text {nd }}$ Junior Olympic Game 2014. Using WAGR ranking, as on 08.06.2014, they will summarize ranking scores of girls and boys of every country. So 26 countries with the best indicators will be admitted to qualification [http://olympic.ru].

WAGR- tournaments have been conducted in Ukraine since 2011. The first was women golf tournament Ukrainian Ladies Open Amateur Championship 2011. Since that time Ukraine accepted six WAGR- tournaments and place in WAGR ranking was taken by seven Ukrainian players (see table 1). To day, after Open Ukrainian golf championship 2014 in WAGR ranking there is only one player from Ukraine and he takes 5691 position [www.ukrgolf.org].

Table 1

Ukrainian golf tournaments, which were included in WAGR schedule

\begin{tabular}{|l|l|}
\hline \multicolumn{1}{|c|}{ Description } & \multicolumn{1}{|c|}{ Date } \\
\hline Ukrainian Open Club Cup Trophy & August 12-14, 2011 \\
\hline $\begin{array}{l}\text { Women tournament of series of European tour LETAS 2012 (Golfstream Ladies Open: } \\
\text { Ladies European Tour Access Series) }\end{array}$ & April 22-24, 2012 \\
\hline
\end{tabular}




\begin{tabular}{|l|l|}
\hline \multicolumn{1}{|c|}{ Description } & \multicolumn{1}{c|}{ Date } \\
\hline Ukrainian Open Amateur Championship, 2012 & July 6-8, 2012 \\
\hline Ukrainian Open Club Cup Trophy, 2012 & August 3-5, 2012 \\
\hline Ukrainian Open Amateur Championship, 2013 & July 5-7, 2013 \\
\hline Ukrainian Open Amateur Team Championship, 2013 & August 2-4, 2013 \\
\hline Ukrainian Open Amateur Championship, 2014 & July 4-6, 2014 \\
\hline Ukrainian Open Amateur Team Championship, 2014 & July 1-3, 2014 \\
\hline
\end{tabular}

\section{Conclusions:}

1. Quantity of players of a country, who got in ranking (WAGR - ranking players) determines progress level of national golf and weight of federation on international arena.

2. Quantity of WAGR - players is one of conditions, under which a country receives right to accept great international golf competitions, including elite championships of amateur golf.

3. For selection of sportsmen for summer Junior Olympic Games they use world ranking of amateur golf players (WAGR) for girls and boys.

The prospects of further researches in this direction imply determination of main trends of golf's development in the world.

\section{References:}

1. Gallakher B., Uilson M. Gol'f dlia nachinaiushchikh [Golf for beginners], Moscow, Fair-Press, 2005, 192 p.

2. Krejg D., Vins S. Anatomiia gol'fa [anatomy golf], 2011, 200 p.

3. Makgimpsi K. Gol'f: istoriia miacha [Golf: The story of the ball], Moscow, ID "Anatolia", 2006, 526 p.

4. Makgimpsi K., Nich D. Gol'f [Golf], Moscow, ID "Anatolia", 2006, 176 p.

5. Michuda Iu. Teoriia i metodika fizichnogo vikhovannia i sportu [Theory and methods of physical education and sport], 2005, vol.1, pp. 30-35.

6. Platonov V. N., Bubka S. N. , Bulatova M.M. Olimpijskij sport [Olympic Sports], Kiev, Olympic Literature, 2009, T.2, 696 p.

7. Pravila gol'fa i Pravila liubitel'skogo statusa 2012-2015 [Rules of Golf and amateur status rules 2012-2015], Moscow, Russian Golf Association, 2012, 210 p.

8. Andrea Sartori. Tendencii razvitiia industrii gol'fa. [Tendencies of development of the golf industry], KPMG, 2013, 12 p.

9. Edmund N. Gol'f [Golf], Moscow, Astrel, 2007, 400 p.

10. Fomin Iu.A. Sport vysshikh dostizhenij: sostoianie, aktual'nye problemy i perspektivy razvitiia [Elite sport: state, current problems and prospects of development], Dokt. Diss., Moscow, 1992. - 403 c.

11. Anderson M. Annotation: Conceptions of intelligence. Journal of Child psychiatry, 2001, vol.42(3), pp. 290-298.

12. Bradbeer R., Morrison I. The ultimate Golfer. N.-Y., Smithmark, 1993, 256 p.

13. Coakley J. Sport in Society: Issues and Controversies. New York, McGraw-Hill, 2004, 240 p.

14. Giulianotti R., Robertson R. Globalization and sport. Blackwell Publishing, 2008, 144 p.

15. Golf advisory practice in EMA. KPMG, 2011, 6 p.

16. Meister C. 75 th Anniversary. European Golf Association. Zwitzerland , 2012, pp. 100-101.

17. Miller D. Olympic revolution. London, Pavilion Book Ltd., 1992, 226 p.

18. Rihm D. The games of golf. - N.Y., 1990, 98 p.

19. Rules of Golf and the Rules of Amateur status 2012-2015 [32end edition]. R\&A Rules Limited and The United States Golf Association, 2012, 208 p.

20. Woods R. Social issues in sport. Champaign, Human Kinetics, 2007, 384 p. 
Information about the author:

Tereshchuk M.V.: ORCID: http://orcid.org/0000-0002-8029-690x;

marina.tereshchuk@ukrgolf.org; National University of Physical Education and Sport of Ukraine; Fizkultury str. 1, Kiev, 03680, Ukraine.

Cite this article as: Tereshchuk M.V. The system of world golf ranking among amateur players - WAGR. Physical education of students, 2014, vol.6, pp. 69-72. doi:10.15561/20755279.2014.0613

The electronic version of this article is the complete one and can be found online at: http://www.sportpedu.org.ua/html/arhive-e.html

This is an Open Access article distributed under the terms of the Creative Commons Attribution License, which permits unrestricted use, distribution, and reproduction in any medium, provided the original work is properly cited (http:/ creativecommons.org/licenses/by/3.0/deed.en).

Received: 10.06 .2014

Published: 30.06 .2014 